\title{
Rodent Models of Focal Stroke: Size, Mechanism, and Purpose
}

\author{
S. Thomas Carmichael \\ Department of Neurology, David Geffen School of Medicine at UCLA, Los Angeles, California 90095
}

\begin{abstract}
Summary: Rodent stroke models provide the experimental backbone for the in vivo determination of the mechanisms of cell death and neural repair, and for the initial testing of neuroprotective compounds. Less than 10 rodent models of focal stroke are routinely used in experimental study. These vary widely in their ability to model the human disease, and in their application to the study of cell death or neural repair. Many rodent focal stroke models produce large infarcts that more
\end{abstract}

closely resemble malignant and fatal human infarction than the average sized human stroke. This review focuses on the mechanisms of ischemic damage in rat and mouse stroke models, the relative size of stroke generated in each model, and the purpose with which focal stroke models are applied to the study of ischemic cell death and to neural repair after stroke. Key Words: Necrosis, apoptosis, neural repair, malignant infarction, rat, mouse.

\section{INTRODUCTION}

Stroke is the third leading cause of death in the United States. With 700,000 cases per year, a person dies from stroke every 3 min. ${ }^{1}$ These statistics have propelled the search for neuroprotective therapies to reduce cell death and infarct volume after stroke. Stroke is also the leading cause of adult disability, because $76 \%$ of people survive their stroke. Of these survivors, $50 \%$ have a hemiparesis, $26 \%$ are dependent in activities of daily living, and $26 \%$ are forced into a nursing home. This long-term disability means that $\$ 30$ billion of the $\$ 53.5$ billion annual dollar cost of stroke is incurred in supporting long-term survivors. ${ }^{1}$ Thus, stroke is a lethal disease, but it disables more than it kills. This fact has led a recent effort to develop strategies for neural repair after stroke. ${ }^{2}$

The push to translate stroke therapies from the animal model to the hospital produced a spate of clinical trials in the 1990s. Many recent reviews have covered the resultant failures in these efforts, as they relate both to limitations in the animal models, and to problems with clinical trial design., ${ }^{3,4}$ Several recent reviews have also focused on the mechanisms of cell death, neuroprotection, and neural repair after stroke. ${ }^{2,4,5}$ This review will deal with the specific aspects of human disease modeled in rodent stroke models of focal ischemic stroke. The

Address correspondence and reprint requests to S. Thomas Carmichael, Department of Neurology, David Geffen School of Medicine at UCLA, 710 Westwood Plaza, Los Angeles, CA 90095. E-mail: Scarmichael@mednet.ucla.edu. development of primate and higher mammal stroke models is an important goal $^{6}$ but without institutional change in animal facilities and costs, rodent models will continue to provide the predominant basic science research into the mechanisms of neuroprotection and neural repair after stroke. Several recent animal models have been designed specifically to determine reparative events in the brain after stroke, and many standard rodent models are best suited to testing neuroprotective therapies. This review will focus on this rough grouping: animal models of acute cell death in stroke, and animal models of neural repair in stroke.

\section{MODELING HUMAN STROKE}

Stroke can occur as end-arteriolar or small vessel occlusion, large artery occlusive disease, artery-to-artery embolism, and cardioembolism. Each source of stroke is associated with different infarct mechanisms and size, ranging from the lacunar strokes of small vessel disease to the large wedge-shaped cortical and subcortical infarctions of embolic stroke. However, large-scale clinical trials and the advent of routine angiographic and brain imaging studies have documented common characteristics of human stroke. Many of these characteristics common to human stroke are well modeled by animal stroke models. These include the concept of evolving stroke damage, in which ischemic cell death or cell stress responses progress after the initial ischemic insult; and the region of the ischemic penumbra, a brain region adjacent 
TABLE 1. Human Stroke Size and Malignant Infarction

\begin{tabular}{lcc}
\hline Volume $\left(\mathrm{cm}^{3}\right)$ & \% Hem & Reference \\
\hline Human Stroke Size & & \\
51 & 8.29 & 7 \\
55 & 8.94 & 8 \\
28 & 4.55 & 11 \\
40 & 6.50 & 11 (Cardioembolic) \\
20 & 3.25 & 12 \\
80 & 13.01 & 12 (Largest subtype) \\
34 & 5.53 & 13 \\
28 & 4.55 & 164 \\
Malignant Human & & \\
Brain Infarction & & 165 \\
240 & 39.02 & 166 \\
244 & 39.67 & 167 \\
293 & 47.64 &
\end{tabular}

Human hemispheric volume taken from Refs. 7-10.

to the earliest region of ischemic cell death that will itself progress to infarction over time unless treated. But three principles in human stroke appear to have been less primarily included in animal models of stroke and warrant discussion.

\section{Small size}

Human strokes are mostly small in size (Table 1). In large population studies and clinical trials, strokes range from $28-80 \mathrm{~mm}^{3}$. Using human hemisphere volumetric measurements, ${ }^{7-10}$ this translates to $4.5-14 \%$ of the ipsilateral hemisphere (Table 1). This relative size holds true in selected subsets of stroke, such as cardioembolic $^{11}$ or larger cortical/subcortical strokes. ${ }^{12}$ Using large clinical trials as a source for overall stroke size may introduce a potential bias in favor of stroke with less severe symptomatology, and hence smaller stroke, as these would be more likely to lead to survival and hospital presentation ${ }^{12,13}$ or inclusion in the trial design. However, it is precisely these most common types of stroke that are the target of neurotherapeutics. This is because larger strokes have worse functional recovery and more often present as malignant infarction.

Malignant infarction comprises approximately $10 \%$ of all strokes and is a syndrome of large stroke producing progressive edema, arterial compression, and infarct expansion. ${ }^{14}$ Medical therapy is largely ineffective, leading to severe brain damage, herniation and death, or emergent craniectomy, and an overall mortality of up to $80 \% .{ }^{14-16}$ Although there has been a clinical proviso that this stroke subtype occurs when infarcts encompass more than $50 \%$ of the ipsilateral cerebral hemisphere on imaging, in fact a comparison of the reported volumes of malignant infarction with estimated cerebral hemispheric size indicates that malignant infarction occurs when the stroke size is greater than $39 \%$ of the ipsilateral hemisphere (Table 1). This is a little less than 10 -fold greater than the reported normal range of nonmalignant human stroke.

\section{Reperfusion}

Human stroke involves a substantial degree of reperfusion. This comes from three sources. First, early clot lysis occurs in 15-18.8\% percent of all strokes as assessed by serial monitoring. ${ }^{17,18}$ Second, collateralization occurs through the circle of Willis and leptomeningeal collaterals. ${ }^{19,20}$ Long a field of some controversy, ${ }^{21}$ leptomeningeal collaterals have been formally shown to provide peri-infarct blood flow and improved outcome in stroke. $^{22-24}$ As intra-arterial therapies grow in importance in stroke, it is likely that additional angiographic studies will document the rapid peri-infarct flow provided by these superficial channels. ${ }^{20}$ Indeed, intra-arterial therapies themselves lead in part to the final source of reperfusion in stroke. The only approved or clinically effective agents in stroke produce reperfusion: intravenous tissue plasminogen activator (tPA), intra-arterial urokinase or tPA, platelet glycoprotein IIb/IIIa receptor antagonists, Ancrod (a fibrinoloytic) and the recently approved intravascular clot retrieval device. ${ }^{25-27}$ As these agents gain more widespread use, the incidence of reperfusion in human stroke will increase.

\section{Patterns of recovery}

Stroke produces behavioral deficits by damaging neuronal circuits specific to a given brain function. This seems obvious to the neuroscientist or neurologist, but both animal models and clinical trials have focused on stroke size irrespective of the circuits that are damaged. ${ }^{28}$ Animal models in particular have focused on reducing the size of large strokes in rodents. However, human deficits after stroke occur with damage to specific circuits, such as in motor cortex maps, ${ }^{29}$ and recovery follows a reproducibly determined functional reorganization in the brain. Motor, sensory, and language recovery involves a progressive reorganization and recovery of activation in peri-infarct and ipsilateral connected cortical sites after stroke. ${ }^{30-34}$ Successful rehabilitative therapies, such as constraint-induced therapy, ${ }^{35-37}$ increase this functional remapping in brain areas adjacent to stroke. Thus, to go beyond studies of cell death, modeling neural repair in human stroke will require that animal stroke models produce injury in defined brain circuits so as to identify the molecular and cellular events that produce reorganization and recovery in the spared circuits adjacent to the infarct.

\section{ANIMAL MODELS OF CELL DEATH IN STROKE}

Animal models of cell death in stroke are designed to generate reproducible infarcts in a high throughput manner with a minimum of surgical manipulation to deter- 
mine mechanisms of cell death and test neuroprotective therapies. MCAo [intra-arterial suture occlusion of the middle cerebral artery (MCA)] through the internal carotid artery is the most widely used and has been extended to the mouse in recent genetic studies of cell death mechanisms. Most of these models have advantages in following the human stroke condition of large artery occlusion, are technically not difficult to perform, and can be applied to studies of stroke and cell death in the aged brain without prohibitive time or cost constraints. However in some forms, rodent models of cell death in stroke produce very large infarcts that may not model the most common, and treatable, human strokes.

\section{MCAo}

MCAo was introduced by Kozuimi et al. ${ }^{38}$ and subsequently modified to reduce subarachnoid hemorrhage and premature reperfusion by coating the suture, such as with silicone. ${ }^{39,40}$ This technique involves transecting the external carotid artery, temporarily tying off the common carotid artery and using the external carotid artery trunk as a side path to pass a suture through the internal carotid artery to lodge in the junction of the anterior and middle cerebral arteries. The suture can be left in place for a variable duration of time and then removed to produce reperfusion. The most common durations of suture occlusion of the MCA in the rat are 60, 90, and 120 min and permanent occlusion. This technique does not require craniotomy, produces focal occlusion of a large cerebral artery as seen in human stroke and can be done in a high throughput manner. However, even with modifications such as coating the suture, MCAo is associated with an approximate $12 \%$ rate of subarachnoid hemorrhage, which reduces cerebral blood flow bilaterally. ${ }^{40,41}$ Also, transection of the ECA renders the muscles of mastication and swallow ischemic, producing difficulty in eating and weight loss. Although this does not alter overall infarct size, it is associated with poorer performance on post-stroke behavioral outcome measures. ${ }^{42}$

MCAo produces primary ischemic cell death in striatum and overlying frontal, parietal, temporal, and portions of occipital cortex, but also variable damage in the thalamus, cervicomedullary junction, substantia nigra, and hypothalamus. ${ }^{43-45}$ Damage to widespread and functionally diverse brain regions is likely to produce complex motor, sensory, autonomic, and cognitive deficits and confound study of the specific circuits involved in recovery of these functions after stroke. In suture occlusion of 60 min duration or greater, hypothalamic damage is robust and occurs early. ${ }^{43,46}$ Hypothalamic ischemia is rarely seen in human stroke. Hypothalamic ischemia generates a hyperthermic response in rats that persists for at least $1 \mathrm{~d}$ after the animal has recovere ${ }^{46}$ and is often unmonitored. Hyperthermia exacerbates cell death and this means that temperature fluctuations themselves may be a source of variability in ischemic cell death in MCAo. ${ }^{46-48}$ Historically, this confounded early neuroprotective studies, particularly for MK-801. It is now clear that the primary neuroprotective effect of MK-801 is mediated through its hypothermic effect, and not through NMDA antagonism in the excitotoxic infarct bed. ${ }^{49}$

The most consistent pattern of cell death in MCAo follows a well-described progression from early infarction in the striatum to delayed infarction in the dorsolateral cortex overlying the striatum. Striatal infarction is mostly necrotic, occurs rapidly, ${ }^{43,50}$ and is resistant to most neuroprotective agents administered after the procedure. ${ }^{51-55}$ Cortical infarction is more delayed, involves a prolonged and biphasic opening of the blood brain barrier, and contains a greater degree of apoptotic cell death than in striatal infarction. ${ }^{43,50,56,57}$ In MCAo with reperfusion, the striatum remains densely ischemic, but the overlying cortex returns to control blood flow values. ${ }^{58}$ Thus, in MCAo striatal infarction is an ischemic core, and cortical infarction is a region of delayed, progressive neuronal death, or an ischemic penumbra. Consistent with this idea, many hypoxia-induced genes involved in neuroprotection are induced solely in cortex after MCAo, such as heat shock protein $70, \mathrm{Bcl}-2, \mathrm{Bcl}-$ $\mathrm{XL}$, and Bax. ${ }^{59-61}$ The progressive cell death in dorsolateral cortex is also associated with delayed inflammatory mediators of ischemic cell death, including neutrophil invasion, tumor necrosis factor $\alpha$ and interleukin- $1 \beta$ cytokine release, inducible nitric oxide synthase and cyclooxygenase-2 activation ${ }^{62-65}$ as well as oxidative cellular injury. ${ }^{66}$ The delayed progression of cell death in cortex in MCAo is an advantage of this model. The time course and clinical realities of human stroke make the ischemic penumbra, and secondary mediators of ischemic cell death such as inflammation and oxidative injury, the main targets for neuroprotective therapies. $^{3,4}$

\section{Mouse MCAo}

Intraarterial suture occlusion of the middle cerebral artery is the most common focal stroke model in the mouse. As with rat MCAo, MCAo in the mouse avoids skull soft tissue damage, prolonged surgery time and animal morbidity associated with craniotomy. Subarachnoid hemorrhage affects roughly $10 \%$ of MCAo in the mouse ${ }^{67}$ Unlike rat MCAo, MCAo in the mouse leads to hypothermia. ${ }^{68}$ Hypothalamic damage occurs in both species, but the large surface area/volume of the mouse leads to temperature loss in the postoperative period. ${ }^{68}$ Also unlike rat MCAo, MCAo in the mouse is uniquely plagued by substantial variations in the volume of damage within and between strains and by the easy possibility of generating large infarcts in widespread and diverse brain structures. 
Mice exhibit profound interstrain differences in infarct volume after MCAo. In several studies of permanent suture-induced MCAo, C57BL/6 mice exhibit significantly larger infarct volumes than Sv12969,70 and in global ischemia C57BL6 is more sensitive than BALBc and other strains. ${ }^{71}$ Interestingly, in distal MCAo (see below), BALBc mice have larger strokes than C57BL/6 and Sv129 strains. ${ }^{72-74}$ There are strain differences in arterial collaterals and sensitivity to excitotoxic cell death that may partially account for these differences. C57BL/6 have poorly developed posterior communicating arteries, ${ }^{71,75,76}$ which will limit collateral flow to the territory distal to an occluded MCA. However, the degree of development of the circle of Willis does not strictly correlate with distal blood flow ${ }^{71,72}$ or with infarct size. $^{77}$ Of the commonly used mice strains, C57BL/6 and BALB/c are more resistant than Sv129 and FVB/N mice to kainite-induced excitotoxic hippocampal damage ${ }^{78}$ which is the inverse pattern of sensitivity to suture-induced MCAo. Thus, the mechanism for this interstrain difference in ischemic cell death remains to be determined. However, mouse strains have differences in many gene systems, including those related to cytokine and major histocompatibility complex expression, glial reactivity, and intracellular protein processing ${ }^{73,79}$ that may contribute to differential sensitivity to ischemic cell death. An important point of this variability is that principles of cell death or neuroprotection derived from a single mouse strain should be replicated in additional strains before they are considered as generalized fact.

Arterial occlusion in the mouse produces a steep relationship between occlusion time and increases in ischemic cell death. The difference between 15 and $30 \mathrm{~min}$ of MCAo is a fivefold increase in infarct volume in C57BL/6 mice. ${ }^{76}$ Similarly, in bilateral common carotid artery occlusion, 6 min of interruption of blood flow produces no ischemic damage, but 8 min produces damage to striatum and hippocampus in C57BL/6. ${ }^{80}$ The exquisite sensitivity of the mouse to infarct extension over minutes of MCAo may account for the variation in infarct size in this model: published studies of infarct size within the same strain, using the same duration of MCAo and the same survival period produce measures of infarct volume that range over a fivefold difference (see Table 2). When infarct size extends into larger volumes in the mouse, the damage involves a substantial amount of the cerebral hemisphere and very different brain structures, including most of the ipsilateral cortex, striatum, thalamus, hippocampus, pyriform cortex, accumbens, and the subventricular zone. ${ }^{70,76,81}$ The progression of ischemic cell death in mouse MCAo mirrors that in rat, with comparable events shifted toward shorter MCAo occlusion times. Thus, with brief MCAo (30 $\mathrm{min})$, there is rapid infarction in the striatum, and delayed infarction in overlying cortex, associated with heat shock protein and immediate early gene induction in cortex. ${ }^{82}$ With longer MCAo, such as $1 \mathrm{~h}$ and permanent occlusion, there is widespread, simultaneous damage in both striatum and cortex, and indeed much of the ipsilateral cerebral hemisphere ${ }^{83,84}$ with a small region of pernumbral cortex. Thus brief MCAo in the mouse (30 $\mathrm{min})$ resembles longer MCAo in the rat (60-120 $\mathrm{min})$, but longer MCAo in the mouse (60-120 min) produces rapid, simultaneous infarction in much of the cerebral hemisphere.

\section{Modeling malignant infarction}

Suture occlusion of the MCA in the mouse and rat frequently produces tissue damage in a substantial portion of the ipsilateral cerebral hemisphere. When a large number of recent or important past publications are surveyed and normalized for hemispheric volume, infarct size in both species ranges from around 5\% to $50 \%$ of the cerebral hemisphere, with most studies noting infarcts between 21 and $45 \%$ of the ipsilateral hemisphere. This range occurs independently of reperfusion time (Table 2 ). As noted previously, in humans infarcts consistently greater than $39 \%$ of the ipsilateral hemisphere are malignant infarctions (Table 1). These develop substantial edema and progressive infarct expansion, with outcomes of either brain herniation or pan-hemispheric destruction, and minimal functional recovery. Instead, the most common forms of human stroke are not malignant infarctions. These most common humans strokes are approximately an order of magnitude smaller (Table 1) and are all associated with some degree of recovery. In comparing these numbers from rodent and human stroke, it is clear that there is a risk that many studies of MCAo in rodents, and particularly in the mouse, are not modeling the usual cases of human stroke, but are modeling malignant infarction. In fact, it is a unique characteristic of the lissencephalic rodent brain that these animals even survive this large stroke in appreciable numbers. In cats, distal or proximal MCAo of similar occlusion times produces large hemispheric infarctions, progressive edema, and death. ${ }^{85,86}$ In humans, malignant infarction is associated with diminished local collateral flow and a reduced region of penumbra. ${ }^{87,88}$ Similarly in rats, laser Doppler flow measurements suggest that suture occlusion of the MCAo also results in reduced local collateral flow, compared with other stroke models. ${ }^{89}$ Thus, rodent MCAo may in many cases be modeling progressive ischemic cerebral edema, but not small, focal stroke.

\section{Other models of MCAo: distal MCAo and embolic MCAo}

There are two main distal occlusion models of the middle cerebral artery. Both produce more restricted damage to the cerebral hemisphere, avoiding the thalamic, hypothalamic, hippocampal, and midbrain damage seen in suture-occlusion of the MCAo of greater than 
TABLE 2. Rodent Stroke Size

\begin{tabular}{|c|c|c|c|c|c|c|}
\hline Stroke Technique & Strain & Time Point & Volume $\left(\mathrm{mm}^{3}\right)$ & $\%$ of Hem & $\%$ of Hem Calc & Reference \\
\hline \multicolumn{7}{|l|}{ Rat } \\
\hline MCAo 60 & SD & $3 \mathrm{~d}$ & 60 & & 7.43 & 146 \\
\hline MCAo 60 & Wistar & $14 \mathrm{~d}$ & 82 & & 10.16 & 147 \\
\hline MCAo 60 & SD & $24 \mathrm{~h}$ & 400 & & 49.57 & 147 \\
\hline MCAo 60 & SD & $24 \mathrm{~h}$ & 160 & & 19.83 & 46 \\
\hline MCAo 60 & SD & $3 d$ & 48 & & 5.95 & 39 \\
\hline MCAo60 & SD & $24 \mathrm{~h}$ & 400 & & 49.57 & 148 \\
\hline MCAo 60 & SD & $24 \mathrm{~h}$ & 270 & & 33.46 & 149 \\
\hline MCAo 90 & SD & $24 \mathrm{~h}$ & 180 & & 22.30 & 46 \\
\hline MACo 90 & SD & $1 \mathrm{~d}$ & & $22 \%$ & & 150 \\
\hline MCAo 90 & SD & $7 \mathrm{~d}$ & 65 & & 8.05 & 39 \\
\hline MCAo 120 & Wistar & $4 \mathrm{~d}$ & & $22 \%$ & & 41 \\
\hline MCAo 120 & Wistar & $3 \mathrm{~d}$ & 261 & & 32.34 & 151 \\
\hline MCAo120 & SD & $24 \mathrm{~h}$ & 220 & & 27.26 & 46 \\
\hline MCAо120 & SD & $3 \mathrm{~d}$ & 122 & & 15.12 & 39 \\
\hline MCAo 120 & SD & $24 \mathrm{~h}$ & 243 & & 30.11 & 103 \\
\hline MCAO 120 & SD & $3 \mathrm{~d}$ & 211 & & 26.15 & 152 \\
\hline MCAO 120 & Wistar & $4 d$ & & $22 \%$ & & 41 \\
\hline MCAO 120 & Wistar & $24 \mathrm{~h}$ & 379 & & 46.96 & 152 \\
\hline MCAo perm & Wistar & $1 \mathrm{~d}$ & 305 & & 37.79 & 42 \\
\hline MCAo perm & SD & $72 \mathrm{~h}$ & & $38 \%$ & & 129 \\
\hline MCAo perm & SD & $24 \mathrm{~h}$ & 240 & & 29.74 & 46 \\
\hline MCAo perm & Wistar & $24 \mathrm{~h}$ & 317 & & 39.28 & 90 \\
\hline MCAo perm & SD & $24 \mathrm{~h}$ & 273 & & 33.83 & 153 \\
\hline MCAo perm & SD & $24 \mathrm{~h}$ & & $33 \%$ & & 99 \\
\hline MCAo thrombus & SD & $24 \mathrm{~h}$ & 178 & & 22.06 & 103 \\
\hline MCAo thrombus & SD & $5 \mathrm{~d}$ & & $37 \%$ & & 154 \\
\hline Tamura & F344 & $24 \mathrm{~h}$ & 159 & & 19.70 & 90 \\
\hline Tamura & Wistar & $24 \mathrm{~h}$ & 99 & & 12.27 & 90 \\
\hline Tamura & SD & $84 \mathrm{~d}$ & & $22 \%$ & & 155 \\
\hline Tamura & F344 & $24 \mathrm{~h}$ & 68 & & 8.43 & 152 \\
\hline Three-vessel $60 \mathrm{~min}$ & SD & $48 \mathrm{~h}$ & 213 & & 26.39 & 95 \\
\hline Three-vessel $90 \mathrm{~min}$ & SD & $48 \mathrm{~h}$ & 116 & & 14.37 & 95 \\
\hline Three-vessel $120 \mathrm{~min}$ & SD & $48 \mathrm{~h}$ & 164 & & 20.32 & 95 \\
\hline Three-vessel $120 \mathrm{~min}$ & Wistar & $24 \mathrm{~h}$ & 150 & & 18.59 & 96 \\
\hline Three-vessel $180 \mathrm{~min}$ & Wistar & $24 \mathrm{~h}$ & 211 & & 26.15 & 96 \\
\hline Three-vessel perm & Wistar & $24 \mathrm{~h}$ & 214 & & 26.52 & 96 \\
\hline \multicolumn{7}{|l|}{ Mouse } \\
\hline MCAo 15 & C57 & $24 \mathrm{~h}$ & 9 & & 5.00 & 76 \\
\hline MCAo 30 & C57 & $24 \mathrm{~h}$ & 56 & & 31.11 & 76 \\
\hline MCAo 30 & C57 & $24 \mathrm{~h}$ & 20 & & 11.11 & 81 \\
\hline MCAo 30 & $\mathrm{C} 57$ & $24 \mathrm{~h}$ & 52 & & 28.89 & 156 \\
\hline MCAo 30 & C57 & $24 \mathrm{~h}$ & 56 & & 31.11 & 76 \\
\hline MCAo 30 & C57 & $24 \mathrm{~h}$ & 67 & & 37.22 & 157 \\
\hline MCAo 30 & $\mathrm{C} 57$ & $24 \mathrm{~h}$ & 100 & & 55.56 & 158 \\
\hline MCAo 30 & C57 & $24 \mathrm{~h}$ & 23 & & 12.78 & 67 \\
\hline MCAo 60 & C57 & $24 \mathrm{~h}$ & 69 & & 38.33 & 76 \\
\hline MCAo 60 & C57 & $24 \mathrm{~h}$ & 30 & & 16.67 & 81 \\
\hline MCAo 60 & C57 & $48 \mathrm{~h}$ & 22 & & 12.22 & 159 \\
\hline MCAо 60 & C57 & $24 \mathrm{~h}$ & 69 & & 38.33 & 76 \\
\hline MCAO 90 & C57 & $3 \mathrm{~d}$ & 59 & & 32.78 & 160 \\
\hline MCAo 120 & C57 & $24 \mathrm{~h}$ & 28 & & 15.56 & 81 \\
\hline MCAo 180 & C57 & $24 \mathrm{~h}$ & 37 & & 20.56 & 81 \\
\hline MCAo perm & C57 & $18 \mathrm{~h}$ & & $48 \%$ & & 161 \\
\hline MCAo perm & CD-1 & $24 \mathrm{~h}$ & 46 & & 25.56 & 104 \\
\hline MCAo perm & C57 & $24 \mathrm{~h}$ & 40 & & 22.22 & 67 \\
\hline Tamura & CD-1 & $24 \mathrm{~h}$ & 41 & & 22.78 & 152 \\
\hline Three-vessel $15 \mathrm{~min}$ & C57 & $24 \mathrm{~h}$ & 25 & & 13.89 & 95 \\
\hline Three-vessel $30 \mathrm{~min}$ & C57 & $24 \mathrm{~h}$ & 33 & & 18.33 & 95 \\
\hline Three-vessel $60 \mathrm{~min}$ & C57 & $24 \mathrm{~h}$ & 37 & & 20.56 & 95 \\
\hline Distal MCAo & NMRI & $24 \mathrm{~h}$ & 26 & & 14.44 & 162 \\
\hline Distal MCAo & BALBc & $24 \mathrm{~h}$ & 23 & & 12.78 & 162 \\
\hline Distal MCAo & C57 & $3 d$ & 25.2 & & 14.00 & 74 \\
\hline Distal MCAo & BALBc & $3 \mathrm{~d}$ & 44.1 & & 24.50 & 74 \\
\hline
\end{tabular}

Rat hemispheric size taken from Refs. 45 and 162; Mouse hemispheric size taken from Refs. 163 and 164.

$\mathrm{SD}=$ Sprague-Dawley; C57 = C57BL6; $\mathrm{d}=$ day. 
$60 \mathrm{~min}$. As a result, there is no hyperthermic response in these models. ${ }^{47}$ In a method originally developed by Tamura et al., ${ }^{89}$ the MCA is transected after it gives off lencticulostriate branches at the basal surface of the lateral part of the cerebral hemisphere. Most investigators do not divide the zygomatic arch as was originally described, but the surgical approach still involves skillful separation of the parotid gland and temporalis muscle and a narrow craniotomy over the MCA. ${ }^{44,72,73,90,91}$ The ischemic damage includes much of the striatum, subcortical white matter, and ipsilateral cortex (Table 2). The second technique involves occlusion of the MCA on the surface of the brain, and bilateral common carotid occlusion-the three-vessel occlusion model. For a consistent infarction in normotensive animals (i.e., not the spontaneously hypertensive stain of rat), there needs to be a period of at least $60 \mathrm{~min}$ in the rat in which the MCA on the surface of the brain and both common carotids are occluded. ${ }^{91-94}$ In the rat, variations on the three-vessel occlusion model relate to whether the MCA and ipsilateral carotid arteries are permanently or transiently occluded. These variations include permanent occlusion of the ipsilateral common and middle cerebral carotid arteries, ${ }^{92}$ permanent occlusion of the ipsilateral common carotid artery alone, ${ }^{95}$ permanent occlusion of the middle cerebral artery alone, ${ }^{94}$ and temporary occlusion of all three vessels. ${ }^{96}$ A comparison of infarct size across these variations suggests that this approach generates a reproducible infarct volume, especially within the same lab. ${ }^{94}$ Ischemic damage involves most of the frontal, parietal, temporal and rostral occipital cortex, the underlying white matter and a small region of dorsolateral striatum. ${ }^{92,94,96}$ Importantly, both the Tamura and three-vessel occlusion models involve reperfusion. In the Tamura model, local collaterals from the anterior cerebral artery provide a zone of reflow in medial frontal and parietal cortex. ${ }^{89,97,98}$ and in the three-vessel models removal of the transient occlusion on the common carotids, or middle cerebral artery, establishes reperfusion. ${ }^{94-96}$ In the mouse, permanent distal MCA and bilateral common carotid artery occlusion limited to 15 min produces infarction confined to cortex, but common carotid occlusion for $30 \mathrm{~min}$ or more produces elements of global infarction bilaterally in the striatum and globus pallidus (C57BL/6 strain, Ohab, J. and S. T. Carmichel, personal observations). Also in the mouse, permanent occlusion of the MCA and ipsilateral common carotid artery (a two-vessel model) provides a similar degree of cortical infarction as the three vessel rat models. ${ }^{74}$

These distal MCA occlusion models produce an infarct core in the frontal and parietal cortex, and evolving infarction over 3-4 days in adjacent temporal, frontal, and cingulate cortex and dorsolateral striatum, characterized by leukocyte infiltration, cytokine production, caspase activation and apoptosis. ${ }^{44,73,91}$ The advantage of these models compared to suture MCAo is that they produce smaller infarcts (Table 2). The disadvantage is that they require craniotomy, a degree of acquired neurosurgical skill, and more preparation time. A recent modification using Rose-Bengal and photocoagulation of the MCA (see below) through the intact skull in the mouse further improves the distal MCAo in this species. ${ }^{74}$

\section{Embolic MCA occlusion}

Three models use embolic MCA stroke: microsphere/ macrosphere injection or thrombotic clot embolization. The macrosphere technique involves installation of large 300-400 $\mu \mathrm{M}$ diameter spheres into the internal carotid artery. These lodge in the middle cerebral artery and produce an infarct of similar size and location as the permanent suture-occlusion of the MCA, without hypothalamic damage and subsequent hyperthermia. ${ }^{49,99}$ The microsphere model utilizes $50 \mu \mathrm{M}$ diameter spheres, instilled into the MCA or internal carotid artery, that produce smaller, multifocal infarctions throughout the brain, ${ }^{100,101}$ modeling distal and diffuse embolism. Thromboembolic clots use either spontaneously formed clots from autologous blood placed into the MCA, or thrombin-induced clots in the middle cerebral artery, to directly model the clot-induced human stroke. ${ }^{102,103}$ The infarction in this model is smaller and more variable than suture-induced MCAo. ${ }^{103}$ Microvessels in the striatum and cortex are occluded at $1 \mathrm{~h}$, and then cortical vessels clear by $3 \mathrm{~h}$ and striatal microvessels clear by $24 \mathrm{~h}$, suggesting a continuous process of endogenous thrombolysis. ${ }^{104}$ The degree of thrombolysis will differ depending on the mechanism of clot formation: spontaneous ex vivo clot formation versus intravascular clot induction with thrombin. ${ }^{105}$ This model closely mimics human stroke, but produces infarcts of more variable size and location, which will make analysis of neuroprotective treatments difficult. However, it provides an excellent system to evaluate new thrombolytic therapies, especially when coupled with real-time magnetic resonance imaging (MRI) assessment. ${ }^{103}$

\section{Photothrombosis model}

Photothrombotic stroke models use local intravascular photooxidation to generate highly circumscribed ischemic cortical lesions. Rose-bengal or other photosensitive dyes are injected intravenously and irradiated within minutes through the intact skull, generating singlet oxygen, focal endothelial damage, platelet activation, simultaneous microvascular occlusion throughout the irradiated area and secondary ischemia. ${ }^{106,107}$ The region of irradiation can be stereotactically determined so as to place the infarct within functionally distinct cortical areas, such as barrel field or hindpaw somatosensory cortex. ${ }^{108,109}$ Rapidly evolving ischemic cell death occurs in the irradiated cortical bed, as measured by nonselective indicators of cell death, such as terminal deoxynucleoti- 
dyl transferase-mediated biotinylated uridine triphosphate nick end labeling (TUNEL) staining, or indicators of apoptotic progression, such as cytoplasmic cytochrome $c .^{110,111} \mathrm{~T}$ cells infiltrate the edge of the lesion, followed by microglial/macrophage activation and both local and distant cytokine production in cortex. ${ }^{12,113}$ The advantages of this model are the small size of the infarcts, the ability to place the infarct within distinct functional subdivisions of cortex, and the minimal surgical manipulation of the animal. This model has recently been modified in the mouse so that rose-bengal is administered intraperitoneally, further streamlining the technique. ${ }^{111}$ The disadvantages of this model stem from the microvascular insult. There is relatively little ischemic penumbra or region of local collateral flow and reperfusion, as seen in the Tamura and three-vessel occlusion models. ${ }^{90,94}$ This is supported by the finding of oxidative damage within the infarct core, rather than progressively distributed in peri-infarct areas as in other models. ${ }^{66,111,114,115}$ Also the simultaneous disruption of endothelial integrity and rapidly progressive infarction in a small cortical volume results in substantial local vasogenic edema. ${ }^{106}$ MRI of photothrombotic stroke shows early increases in T2 signal at the same time as decreased apparent diffusion of water, indicating the simultaneous development of substantial vasogenic edema at the same time as ischemic infarction. ${ }^{116,117}$ In acute brain lesions, T2 signal is a function of extracellular water. This means that photothrombosis induces simultaneous vasogenic (extracellular) edema and cytotoxic (intracellular) edema, i.e., leaky vessels and swollen cells at the same time. This is a very different pattern than seen in human stroke, where infarcts develop with decreased diffusion of water (as measured by the ADC, apparent diffusion coefficient) - a pattern of cytotoxic edema alone that is diagnostic in the acute setting of human focal stroke. ${ }^{118}$ In fact, the simultaneous development of both significant vasogenic and cytotoxic edema in MRI of photothrombotic stroke more closely resembles traumatic brain injury models than focal stroke. ${ }^{119,120}$ Induction of photothrombotic stroke with a ring filter provides a central area within the lesioned cortex that has not been optically thrombosed. ${ }^{121}$ This may provide an area of penumbra, but this potential penumbral area is present within the evolving vasogenic edema and it is unclear if this accurately models the human penumbra.

Despite these limitations in edema and penumbral areas, experiments with photothrombotic stroke have provided a large body of data on changes in neuronal physiology and neurotransmission in peri-infarct and contralateral cortex. Witte and colleagues ${ }^{122,123}$ have used the precise localization of these lesions for both in vivo and slice electrophysiological experiments that have shown increased baseline neuronal firing rates, diminished recurrent neuronal inhibition, and enhanced long- term potentiation after stroke. Diminished GABA $\alpha$ receptor binding and subunit expression, and increased NMDA receptor expression may underlie these physiological changes, and occur within a large region of cortex both ipsi- and contralateral to photothrombotic stroke. ${ }^{109,124}$ These data on cellular and network properties in peri-infarct cortex provide the beginnings of a mechanistic link between early ischemic cell death in stroke, and the later stages of dendritic and axonal sprouting, circuit reorganization and functional remapping that may mediate recovery. ${ }^{2}$ Such a detailed physiological analysis of peri-infarct cortex would be more difficult with lesion models of more variable location in the cerebral hemisphere. It remains to be seen whether the lack of local collateral reflow and reperfusion injury and the profound local edema limit this model in its application to the study of neural repair after stroke.

\section{ANIMAL MODELS OF NEURAL REPAIR IN STROKE}

The study of neural repair after stroke is taking on adding importance as the field develops scientific understanding of the basic cellular mechanisms of neuronal reorganization after injury. As noted above, imaging studies have begun to define consistent patterns of recovery within functional circuits in the human brain after stroke and have implicated peri-infarct cortex and closely connected ipsilateral areas as important in recovery after a stroke. At a cellular level in peri-infarct cortex, axonal sprouting establishes new patterns of cortical connections, ${ }^{2},{ }^{125}$ neural progenitor cells differentiate and send newly born neurons into peri-infarct tissue $\mathrm{e}^{126,127}$ and synaptic plasticity changes the organization of cortical maps. ${ }^{128}$ To define the cellular and molecular mechanisms of these reparative processes requires that an animal model allow direct study of the relevant neuronal circuits as they sprout, differentiate, or re-map after stroke. Most of the animal models of cell death in stroke, including suture occlusion of the MCA, the Tamura model, embolic MCAo and the three-vessel model, produce substantial damage to many different brain regions, sparing very rostral and medial frontal cortex, lateral temporal cortex and occipital cortex ${ }^{89,92,95,129}$ (FIG. 1). In rodents, the connectional structure of these areas is not well established and difficult to study for the patterns of cellular repair after stroke. In contrast, the motor and sensory body maps provide a well described region in which over 50 years of neuroscientific study has defined the anatomy and physiology of the cortical structure. Animal models of stroke in the motor and sensory body maps can use these regions as a template, or circuit board, to determine the basic mechanisms of cellular repair and recovery after stroke. Stroke models in the rodent somatosensory barrel field and fore- 

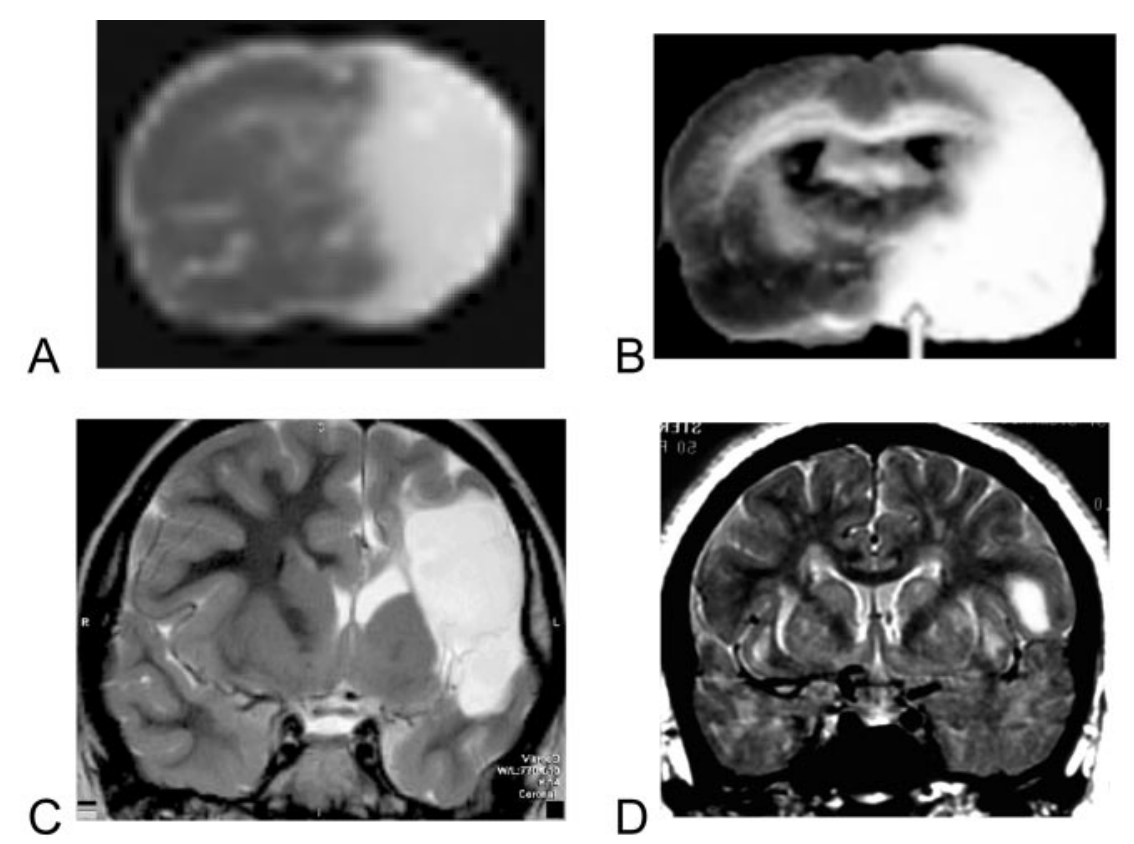

FIG. 1. Stroke in rodent and human. A: TTC stained section from mouse with a 2-h suture occlusion of the MCA 1 day after the infarct was induced. The pale area is the infarcted tissue. B: TTC-stained section from rat with a permanent MCAO, one day after infarct was induced. C: T2-weighted MRI from a patient with a malignant infarction. This patient developed malignant edema and required hemicraniectomy. D: T2-weighted image from a patient with an infarct more representative of average human stroke size (Table 2). Panel A is reprinted with permission from Foerch et al. Serum S100B predicts a malignant course of infarction in patients with acute middle cerebral artery occlusion. Stroke 35:2160-2164. Copyright (C) 2004, Elsevier. All rights reserved. ${ }^{168}$ Panel B is reprinted with permission from Kim et al. Agmatine reduces infarct area in a mouse model of transient focal cerebral ischemia and protects cultured neurons from ischemia-like injury. Exp Neurol 189:122-130. Copyright (C) 2004, Lippincott, Williams and Wilkins. All rights reserved. ${ }^{169}$ Panel C is courtesy of Dr. Noriko Salamon, Division of Diagnostic Neuroradiology, Geffen School of Medicine at UCLA. Panel D is taken from the authors' cases in the UCLA Stroke Service, Geffen School of Medicine at UCLA.

limb sensorimotor cortex have used this template to define principles of neural repair after stroke.

Two models have been applied to produce small focal stroke in rodent somatosensory or motor cortex. One model takes advantage of the arterial branching pattern of the MCA in the parietal region ${ }^{130}$ to focally interrupt blood supply to the somatosensory barrel cortex. ${ }^{115,131}$ The cortical representation of each facial whisker forms a structural module, or barrel, that is easily visualized in the adult brain. Together, these modules constitute the barrel cortex, which forms a significant part of the entire rodent cortex (FIG. 2). To generate reproducible stroke and a component of reperfusion injury, arterial branches to the barrel cortex are permanently interrupted and both common carotids are occluded for one hour. ${ }^{115,125}$ The outcome of this technique is a small cortical stroke in a specific, functionally defined region of the rat barrel field. ${ }^{115,125}$ Because the connections of the barrel field are well established, this model allowed the first definitive description of new patterns of connections, or axonal sprouting, in peri-infarct cortex after stroke. ${ }^{125}$ Small strokes in the barrel field produce successively separated tissue compartments of pan-necrosis; partial tissue damage constituting apoptotic cell death, oxidative DNA damage, and dense reactive gliosis; and cellular stress and distributed gliosis. ${ }^{115}$ Each of the tissue microenvi- ronments is located within distinct functional regions of rat somatosensory and motor cortex. The precise mapping of tissue microenvironments after stroke within a defined cortical structure has allowed comparison of mechanisms of stroke damage between aged and young adults, and identified reduced neuroprotective and cellular stress responses in the aged brain. ${ }^{132} \mathrm{~A}$ similar model has been developed in the mouse (FIG. 2). We have used this model to identify the molecular profile of a neuronal growth program triggered by stroke that mediates axonal sprouting, and a unique region of neuronal regeneration after stroke. ${ }^{133}$ The precise mapping of apoptotic cell death, oxidative DNA damage and partial neuronal injury ${ }^{115}$ also allows definitive study of the molecular profile of glial scar formation in the brain after stroke. ${ }^{133}$ Thus, this model has the advantages of producing strokes of similar size to the most common humans strokes, with a mechanism of reperfusion, in a brain region that serves as a connectional template for the study of reparative processes after stroke. The major disadvantage of this model is that the strokes are variable in size ${ }^{115}$ and this interanimal variability limits study of stroke size, or neuroprotective effect, between treatment groups.

A second model of focal stroke in rodent sensory and motor cortex uses local endothelin-1 application. Endothelin-1 is a potent and long-acting venous and arterial 

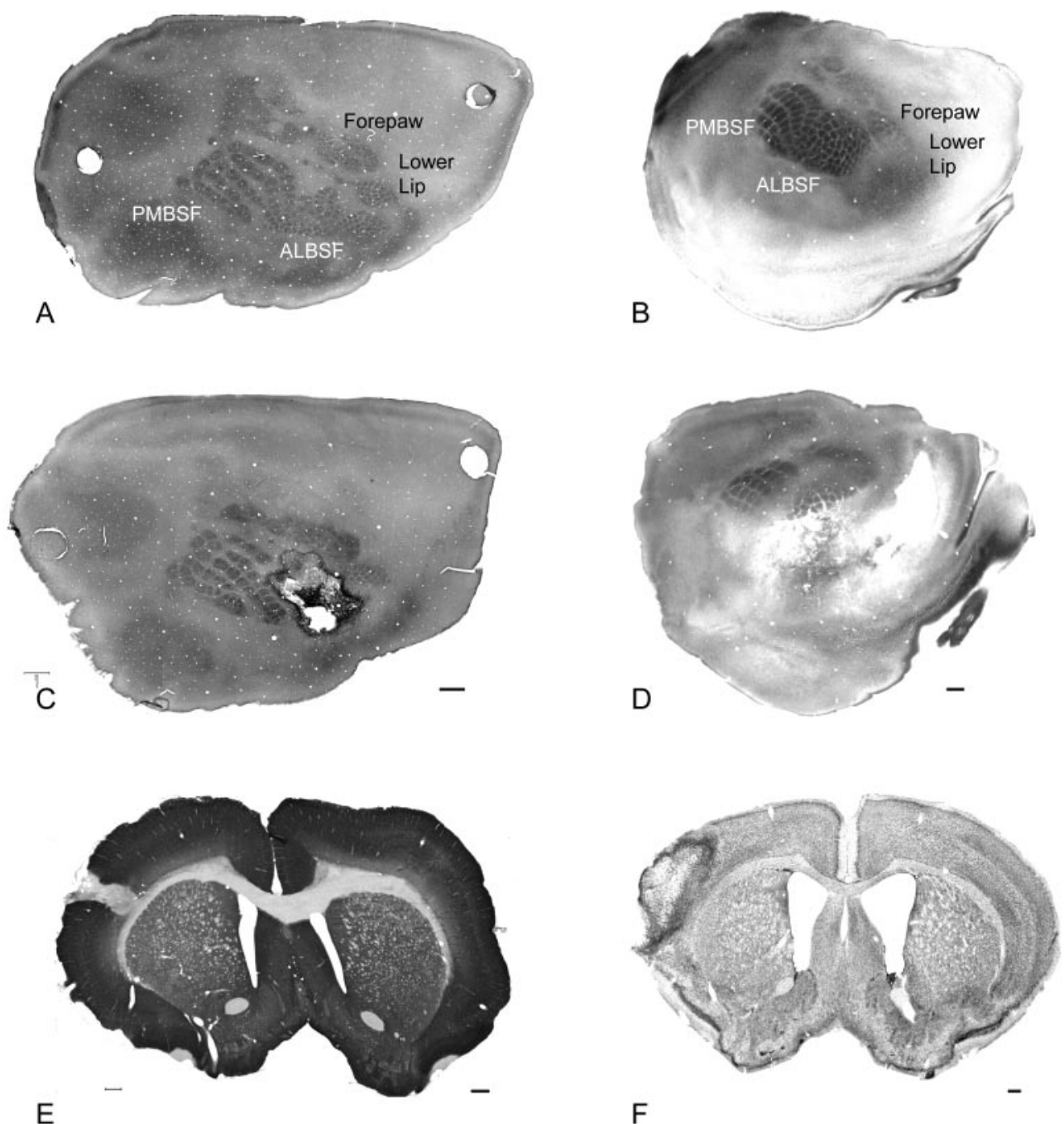

FIG. 2. Focal stroke in rodent barrel field. Left column shows normal and post-stroke rat cortex; right column shows normal and post-stroke mouse cortex. A and C: Tangential sections of flattened rat cortex through cortical layer IV and stained for cytochrome oxidase and nestin shows the rat somatosensory body map. The barrel field (PMBSF and ALBSF) form a significant portion of the total surface area of the rat cortex. In panel C, a stroke has been produced in a portion of the barrel field and is highlighted by dark, nestin-positive reactive astrocytes. E: Coronal section through the infarct stained for MAP2 shows the relatively small total area occupied by the infarct. B and D: Tangential sections of mouse cortex through layer IV and stained for cytochrome oxidase show the somatosensory body map. The infarct is larger in the mouse, but also positioned within and adjacent to the barrel field. F: Coronal section through the infarct stained for Nissl. Bar in $C=1 \mathrm{~mm}$ and applied to A and C; bar in D $=400 \mu \mathrm{M}$ and applied to B and D. Bar in $\mathrm{E}=1 \mathrm{~mm}$; bar in $\mathrm{F}=250 \mu \mathrm{M}$. PMBSF = posteromedial barrel field; ALBSF = anterolateral barrel field.

vasoconstrictor. ${ }^{134}$ Intracerebral injection or surface application of endothelin-1 produces a local dose dependent ischemic lesion with minimal tissue edema. ${ }^{135,136}$ Endothelin-1 application can be directed to distinct cortical regions to produce localized stroke within specific brain circuits. ${ }^{137,138}$ Endothelin-1 can also be injected into subcortical white matter to produce focal subcortical stroke in the rodent. ${ }^{139}$ This approach potentially offers the ability to direct focal ischemia into deep and superficial brain compartments in an animal model of stroke. However, endothelin-1, endothelin-1-converting enzyme and both subtypes of endothelin-1 receptors are found not only on endothelial cells, but also on neurons and astrocytes in the brain. ${ }^{140,141}$ Endothelin-1 application induces astrocytosis and appears to facilitate axonal sprouting in spinal cord injury. ${ }^{142,143}$ These findings suggest that endothelin-1 exerts a direct, receptor-mediated signaling effect within astrocytes and neurons that may interfere with the production and interpretation of neural repair experiments.

\section{CONCLUSION}

Individual rodent stroke models each capture elements of the human disease. With careful attention to size, 
mechanism, and purpose, selected rodent models can be used to study the major targets of human neuroprotective therapies-reperfusion injury, delayed apoptotic cell death, and inflammatory cascades ${ }^{3,4}$; or the cellular elements of neural repair. Rodent models can be easily shifted to study cell death and repair in aged animals, the actual population target for stroke therapies, without prohibitive cost and time constraints. However, rodent models have many well-recognized limits, such as differences in tolerance to cerebral edema, a small region of subcortical white matter to model lacunar infarction, and important molecular differences in thrombotic, inflammatory, and DNA repair cascades compared with primates. ${ }^{144,145}$ In reality, biomedical funding and space constraints make the animal modeling of stroke a progressive endeavor, with intellectual risk and discovery carried out in rodent stroke models and concept replication and proof of principle carried through primate models.

Acknowledgments: This work was supported by National Institute of Neurological Disorders and Stroke 1R01 NS45729 and the Nathan Shappell fund.

\section{REFERENCES}

1. American Heart Association, Heart Disease and Stroke Statistics Update 2004.http://www.americanheart.org/presenter.jhtml?identifier $=3000090$.

2. Carmichael ST. Plasticity of cortical projections after stroke. Neuroscientist 9:64-75, 2003.

3. Gladstone DJ, Black SE, Hakim AM. Heart and Stroke Foundation of Ontario Centre of Excellence in Stroke Recovery. Toward wisdom from failure: lessons from neuroprotective stroke trials and new therapeutic directions. Stroke 33:2123-2236, 2003.

4. Cheng YD, Al-Khoury L, Zivin JA. Neuroprotection for ischemic stroke: two decades of success and failure. NeuroRx 1:36-45, 2004.

5. Sugawara T, Fujimura M, Noshita N, Kim GW, Saito A, Hayashi $\mathrm{T}$, et al. Neuronal death/survival signaling pathways in cerebral ischemia. NeuroRx 1:17-25, 2004.

6. Stroke Therapy Academic Industry Roundtable. Recommendations for standards regarding preclinical neuroprotective and restorative drugs. Stroke 30:2752-2758, 1999

7. Brott T, Marler JR, Olinger CP, Adams HP Jr, Tomsick T, Barsan WG, et al. Measurements of acute cerebral infarction: lesion size by computed tomography. Stroke 20:871-875, 1989.

8. Lyden PD, Zweifler R, Mahdavi Z, Lonzo L. A rapid, reliable, and valid method for measuring infarct and brain compartment volumes from computed tomographic scans. Stroke 25:24212428, 1994.

9. Nopoulos P, Flaum M, O'Leary D, Andreasen NC. Sexual dimorphism in the human brain: evaluation of tissue volume, tissue composition and surface anatomy using magnetic resonance imaging. Psychiatry Res 98:1-13, 2000.

10. Sowell ER, Peterson BS, Thompson PM, Welcome SE, Henkenius AL, Toga AW. Mapping cortical change across the human life span. Nat Neurosci 6:309-315, 2003.

11. National Institute of Neurological Disorders and Stroke (NINDS) rt-PA Stroke Study Group. Effect of intravenous recombinant tissue plasminogen activator on ischemic stroke lesion size measured by computed tomography. Stroke 31:2912-2919, 2000.

12. Lindgren A, Norrving B, Rudling O, Johansson BB. Comparison of clinical and neuroradiological findings in first-ever stroke. A population-based study. Stroke 25:1371-1377, 1994.

13. Kissela B, Broderick J, Woo D, Kothari R, Miller R, Khoury J, et al. Greater Cincinnati/Northern Kentucky Stroke Study: volume of first-ever ischemic stroke among blacks in a population-based study. Stroke 32:1285-1290, 2001.

14. Hacke W, Schwab S, Horn M, Spranger M, De Georgia M, von Kummer R. "Malignant" middle cerebral artery territory infarction: clinical course and prognostic signs. Arch Neurol 53:309315, 1996.

15. Berrouschot J, Sterker M, Bettin S, Koster J, Schneider D. Mortal of space-occupying ("malignant") middle cerebral artery infarction under conservative intensive care. Intensive Care Med 24: 620-623, 1998.

16. Schwab S, Steiner T, Aschoff A, Schwarz S, Steiner HH, Jansen $\mathrm{O}$, et al. Early hemicraniectomy in patients with complete middle cerebral artery infarction. Stroke 29:1888-1893, 1998.

17. Molina CA, Montaner J, Abilleira S, Ibarra B, Romero F, Arenillas JF, et al. Timing of spontaneous recanalization and risk of hemorrhagic transformation in acute cardioembolic stroke. Stroke 32:1079-1084, 2001.

18. Kassem-Moussa H, Graffagnino C. Nonocclusion and spontaneous recanalization rates in acute ischemic stroke: a review of cerebral angiography studies. Arch Neurol 59:1870-1873, 2002.

19. Bisschops RH, Klijn CJ, Kappelle LJ, van Huffelen AC, van der Grond J. Collateral flow and ischemic brain lesions in patients with unilateral carotid artery occlusion. Neurology 60:1435-1441, 2003.

20. Kim JJ, Fischbein NJ, Lu Y, Pham D, Dillon WP. Regional angiographic grading system for collateral flow: correlation with cerebral infarction in patients with middle cerebral artery occlusion. Stroke 35:1340-1844, 2004.

21. Brozici M, van der Zwan A, Hillen B. Anatomy and functionality of leptomeningeal anastomoses: a review. Stroke 34:2750-2762, 2003.

22. Ringelstein EB, Biniek R, Weiller C, Ammeling B, Nolte PN, Thron A. Type and extent of hemispheric brain infarctions and clinical outcome in early and delayed middle cerebral artery recanalization. Neurology 42:289-298, 1992.

23. Arnold M, Nedeltchev K, Mattle HP, Loher TJ, Stepper F, Schroth G, et al. Intra-arterial thrombolysis in 24 consecutive patients with internal carotid artery T occlusions. J Neurol Neurosurg Psych 74:739-742, 2003.

24. Schramm P, Schellinger PD, Fiebach JB, Heiland S, Jansen O, Knauth M, et al. Comparison of CT and CT angiography source images with diffusion-weighted imaging in patients with acute stroke within 6 hours after onset. Stroke 33:2426-2432, 2002.

25. Sherman DG, Atkinson RP, Chippendale T, Levin KA, Ng K, Futrell N, et al. Intravenous ancrod for treatment of acute ischemic stroke: the STAT study: a randomized controlled trial. Stroke Treatment with Ancrod Trial. JAMA 283:2395-2403, 2002.

26. Burton A. Abciximab extends treatment window for stroke. Lancet Neurol 2:390, 2003.

27. Schellinger PD, Kaste M, Hacke W. An update on thrombolytic therapy for acute stroke. Curr Opin Neurol 17:69-77, 2004

28. Corbett D, Nurse S. The problem of assessing effective neuroprotection in experimental cerebral ischemia. Prog Neurobiol 54:531-548, 1998.

29. Crafton KR, Mark AN, Cramer SC. Improved understanding of cortical injury by incorporating measures of functional anatomy. Brain 126:1650-1659, 2003.

30. Traversa R, Cicinelli P, Bassi A, Rossini PM, Bernardi G. Mapping of motor cortical reorganization after stroke. A brain stimulation study with focal magnetic pulses. Stroke 28:110-117, 1997.

31. Karbe H, Thiel A, Weber-Luxenburger G, Herholz K, Kessler J, Heiss WD. Brain plasticity in poststroke aphasia: what is the contribution of the right hemisphere? Brain Lang 64:215-230, 1998.

32. Nelles G, Spiekramann G, Jueptner M, Leonhardt G, Muller S, Gerhard H, et al. Evolution of functional reorganization in hemiplegic stroke: a serial positron emission tomographic activation study. Ann Neurol 46:901-919, 1999.

33. Marshall RS, Perera GM, Lazar RM, Krakauer JW, Constantine RC, DeLaPaz RL. Evolution of cortical activation during recovery from corticospinal tract infarction. Stroke 31:656-661, 2000 
34. Calautti C, Leroy F, Guincestre JY, Marie RM, Baron JC. Sequential activation brain mapping after subcortical stroke: changes in hemispheric balance and recovery. Neuroreport 12: 3883-3886, 2001.

35. Liepert J, Bauder H, Wolfgang HR, Miltner WH, Taub E, Weiller C. Treatment-induced cortical reorganization after stroke in humans. Stroke 31:1210-1216, 2000.

36. Schaechter JD, Kraft E, Hilliard TS, Dijkhuizen RM, Benner T, Finklestein SP, et al. Motor recovery and cortical reorganization after constraint-induced movement therapy in stroke patients: a preliminary study. Neurorehabil Neural Repair 16:326-338, 2002.

37. Wittenberg GF, Chen R, Ishii K, Bushara KO, Eckloff S, Croarkin $\mathrm{E}$, et al. Constraint-induced therapy in stroke: magneticstimulation motor maps and cerebral activation. Neurorehabil Neural Repair 17:48-57, 2003.

38. Koizumi J, Yoshida Y, Nakazawa T, Ooneda G. Experimental studies of ischemic brain edema. I. A new experimental model of cerebral embolism in which recirculation can introduced into the ischemic area. Jpn J Stroke 8:108, 1986.

39. Belayev L, Alonso OF, Busto R, Zhao W, Ginsberg MD. Middle cerebral artery occlusion in the rat by intraluminal suture. Neurological and pathological evaluation of an improved model. Stroke 27:1616-622, 1996.

40. Schmid-Elsaesser R, Zausinger S, Hungerhuber E, Baethmann A, Reulen HJ. A critical reevaluation of the intraluminal thread model of focal cerebral ischemia: evidence of inadvertent premature reperfusion and subarachnoid hemorrhage in rats by laserDoppler flowmetry. Stroke 29:2162-2170, 1998.

41. Chen TY, Goyagi T, Toung TJ, Kirsch JR, Hurn PD, Koehler RC, et al. Prolonged opportunity for ischemic neuroprotection with selective $\kappa$-opioid receptor agonist in rats. Stroke 35:1180-1185, 2004.

42. Dittmar M, Spruss T, Schuierer G, Horn M. External carotid artery territory ischemia impairs outcome in the endovascular filament model of middle cerebral artery occlusion in rats. Stroke 34:2252-2257, 2003.

43. Garcia JH, Liu KF, Ho KL. Neuronal necrosis after middle cerebral artery occlusion in Wistar rats progresses at different time intervals in the caudoputamen and the cortex. Stroke 26:636642, 1995.

44. Kanemitsu H, Nakagomi T, Tamura A, Tsuchiya T, Kono G, Sano K. Differences in the extent of primary ischemic damage between middle cerebral artery coagulation and intraluminal occlusion models. J Cereb Blood Flow Metab 22:1196-1204, 2002.

45. Williams AJ, Berti R, Dave JR, Elliot PJ, Adams J, Tortella FC. Delayed treatment of ischemia/reperfusion brain injury: extended therapeutic window with the proteosome inhibitor MLN519. Stroke 35:1186-1191, 2004.

46. Li F, Omae T, Fisher M. Spontaneous hyperthermia and its mechanism in the intraluminal suture middle cerebral artery occlusion model of the rat. Stroke 30:2464-2471, 1999.

47. Yamashita K, Busch E, Wiessner C, Hossmann KA. Thread occlusion but not electrocoagulation of the middle cerebral artery causes hypothalamic damage with subsequent hyperthermia. Neurol Med Chir (Tokyo) 37:723-727, 1997.

48. Reglodi D, Somogyvari-Vigh A, Maderdrut JL, Vigh S, Arimura A. Postischemic spontaneous hyperthermia and its effects in middle cerebral artery occlusion in the rat. Exp Neurol 163:399-407, 2000.

49. Gerriets T, Stolz E, Walberer M, Kaps M, Bachmann G, Fisher M. Neuroprotective effects of MK-801 in different rat stroke models for permanent middle cerebral artery occlusion: adverse effects of hypothalamic damage and strategies for its avoidance. Stroke 34:2234-2239, 2003.

50. Li Y, Chopp M, Jiang N, Zhang ZG, Zaloga C. Induction of DNA fragmentation after 10 to 120 minutes of focal cerebral ischemia in rats. Stroke 26:1252-1257, 1995.

51. Mohamed AA, Gotoh O, Graham DI, Osborne KA, McCulloch J, Mendelow AD, et al. Effect of pretreatment with the calcium antagonist nimodipine on local cerebral blood flow and histopathology after middle cerebral artery occlusion. Ann Neurol 18: 705-711, 1985.
52. Buchan AM, Xue D, Huang ZG, Smith KH Lesiuk H. Delayed AMPA receptor blockade reduces cerebral infarction induced by focal ischemia. Neuroreport 2:473-476, 1991.

53. Sydserff SG, Borelli AR, Green AR, Cross AJ. Effect of NXY059 on infarct volume after transient or permanent middle cerebral artery occlusion in the rat; studies on dose, plasma concentration and therapeutic time window. Br J Pharmacol 135:103112, 2002.

54. Minematsu K, Fisher M, Li L, Davis MA, Knapp AG, Cotter RE, McBurney RN, et al. Effects of a novel NMDA antagonist on experimental stroke rapidly and quantitatively assessed by diffusion-weighted MRI. Neurology 43:397-403, 1993.

55. Yrjanheikki J, Tikka T, Keinanen R, Goldsteins G, Chan PH, Koistinaho J. A tetracycline derivative, minocycline, reduces inflammation and protects against focal cerebral ischemia with a wide therapeutic window. Proc Natl Acad Sci USA 96:1349613500, 1999.

56. Linnik MD, Miller JA, Sprinkle-Cavallo J, Mason PJ, Thompson FY, Montgomery LR, et al. Apoptotic DNA fragmentation in the rat cerebral cortex induced by permanent middle cerebral artery occlusion. Brain Res Mol Brain Res 32:116-124, 1995.

57. Li Y, Chopp M, Jiang N, Yao F, Zaloga C. Temporal profile of in situ DNA fragmentation after transient middle cerebral artery occlusion in the rat. J Cereb Blood Flow Metab 15:389-397, 1995.

58. Takagi K, Zhao W, Busto R, Ginsberg MD. Local hemodynamic changes during transient middle cerebral artery occlusion and recirculation in the rat: a [14C]iodoantipyrine autoradiographic study. Brain Res 691:160-168, 1995.

59. Gillardon F, Lenz C, Waschke KF, Krajewski S, Reed JC, Zimmermann M, Kuschinsky W. Altered expression of Bcl-2, Bcl-X, Bax, and c-Fos colocalizes with DNA fragmentation and ischemic cell damage following middle cerebral artery occlusion in rats. Brain Res Mol Brain Res 40:254-260, 1996.

60. Schmidt-Kastner R, Truettner J, Zhao W, Belayev L, Krieger C, Busto R, et al. Differential changes of bax, caspase-3 and p21 mRNA expression after transient focal brain ischemia in the rat. Brain Res Mol Brain Res 79:88-101, 2000.

61. Sharp FR, Lu A, Tang Y, Millhorn DE. Multiple molecular penumbras after focal cerebral ischemia. J Cereb Blood Flow Metab 20:1011-1132, 2000.

62. Wang XK, Yue T-L, Barone FC, White RF, Young PR, McDonnell PC, et al. Concomitant cortical expression of TNF $\alpha$ and IL-1 $\beta$ mRNA following transient focal ischemia. Mol Chem Neuropathol 23:103-114, 1994.

63. Zhang Rl, Chopp M, Chen H, Garcia JH. Temporal profile of ischemic damage, neutrophil response, and vascular plugging following permanent and transient $(2 \mathrm{H})$ middle cerebral artery occlusion in the rat. J Neurol Sci 125:3-10, 1994.

64. Yokota C, Kaji T, Kuge Y, Inoue H, Tamaki N, Minematsu K. Temporal and topographic profiles of cyclooxygenase-2 expression during $24 \mathrm{~h}$ of focal brain ishemia in rats. Neurosci Lett 357:219-222, 2004.

65. Zhu DY, Deng Q, Yao HH, Wang DC, Deng Y, Liu GQ. Inducible nitric oxide synthase expression in the ischemic core and penumbra after transient focal cerebral ischemia in mice. Life Sci 71:1985-1996, 2002.

66. Nagayama T, Lan J, Henshall DC, Chen D, O'Horo C, Simon RP, Chen J Induction of oxidative DNA damage in the peri-infarct region after permanent focal cerebral ischemia. $J$ Neurochem 75:1716-1728, 2000.

67. Tsuchiya D, Hong S, Kayama T, Panter SS, Weinstein PR. Effect of suture size and carotid clip application upon blood flow and infarct volume after permanent and temporary middle cerebral artery occlusion in mice. Brain Res 970:131-139, 2003.

68. Barber PA, Hoyte L, Colbourne F, Buchan AM. Temperatureregulated model of focal ischemia in the mouse: a study with histopathological and behavioral outcomes. Stroke 5:1720-1725, 2004.

69. Connolly ES, Winfree CJ, Stern DM, Solomon RA, Pinsky DJ. Procedural and strain-related variables signficantly affect outcome in a murine model of focal cerebral ischemia. Neurosurgery 38:523-532, 1996. 
70. Maeda K, Hata R, Hossmann KA. Regional metabolic disturbances and cerebrovascular anatomy after permanent middle cerebral artery occlusion in C57Black/6 and SV129. Neurobiol Dis 6:101-108, 1999.

71. Yang G, Kitagawa K, Matshushita K, Mabuchi T, Yagita Y, Yanagihara T, Matsumoto M. C57BL/6 stain is most susceptible to cerebral ischemia following bilateral common carotid occlusion among seven mouse strains: selective neuronal death in the murine transient forebrain ischemia. Brain Res 752:209-218, 1997.

72. Majid A, He YY, Gidday JM, Kaplan SS, Gonzales ER, Park TS, et al. Differences in ischemic vulnerability to permanent cerebral ischemia among 3 common mouse strains. Stroke 31:2707-2714, 2001.

73. Lambertsen KL, Gregersen R, Finsen B. Microglial-macrophage synthesis of tumor necrosis factor after focal cerebral ischemia in mice is strain dependent. J Cereb Blood Flow Metab 22:785-797, 2002.

74. Sugimori H, Yao H, Ooboshi H, Ibayashi S, Iida M. Krypton laser-induced photothrombotic distal middle cerebral artery occlusion without craniectomy in mice. Brain Res Brain Res Protoc 13:189-196, 2004.

75. Beckmann $\mathrm{N}$ High resolution magnetic resonance angiography non-invasively reveals mouse strain differences in the cerebrovascular anatomy in vivo. Magn Reson Med 44:252-258, 2000.

76. McColl BW, Carswell HV, McCulloch J, Horsburgh K. Extension of cerebral hypoperfusion and ischaemic pathology beyond MCA territory after intraluminal filament occlusion in C57B1/6 J mice. Brain Res 997:15-23, 2004.

77. Furuya K, Kawahara N, Kawai K, Toyoda T, Maeda K, et al. Proximal occlusion of the middle cerebral artery in C57Black6 mice: relationship of patency of the posterior communicating artery, infarct evolution, and animal survival. J Neurosurg 100: 97-105, 2004.

78. Schauwecker, PE, Steward O. Genetic determinants of susceptibility to excitotoxic cell death: implications for gene targeting approaches. Proc Natl Acad Sci USA 94:4103-4108, 1997.

79. Fernandes C, Paya-Cano JL, Sluyter F, D'Souza U, Plomin R, Schalkwyk LC. Hippocampal gene expression profiling across eight mouse inbred strains: towards understanding the molecular basis for behaviour. Eur J Neurosci 19:2576-2582, 2004.

80. Wu C, Zhan R, Qi S, Fujihara H, Taga K, Shimoji K. A forebrain ischemic preconditioning model established in C57Black/Crj6 mice. J Neurosci Methods 107:101-106, 2001.

81. Belayev L, Busto R, Zhao W, Fernandez G, Ginsberg MD. Middle cerebral artery occlusion in the mouse by intraluminal suture coated with poly-L-lysine: neurological and histological validation. Brain Res 833:181-190, 1999.

82. Hermann DM, Kilc E, Hata R, Hossman KA, Mies G. Relationship between metabolic dysfunctions, gene responses and delayed cell death after mild focal cerebral ischemia in mice. Neurosience 104:947-955, 2000.

83. Hata R, Maeda K, Hermann D, Mies G, Hossmann KA. Dynamics of regional brain metabolism and gene expression after middle cerebral artery occlusion in mice. J Cereb Blood Flow Metab 20:306-315, 2000.

84. Hata R, Maeda K, Hermann D, Mies G, Hossmann KA. Evolution of brain infarction after transient focal cerebral ischemia in mice. J Cereb Blood Flow Metab 20:937-946, 2000.

85. Vexler ZS, Roberts TP, Bollen AW, Derugin N, Arieff AI. Transient cerebral ischemia. Association of apoptosis induction with hypoperfusion. J Clin Invest 99:1453-1459, 1997.

86. Toyota S, Graf R, Valentino M, Yoshimine T, Heiss WD. Malignant infarction in cats after prolonged middle cerebral artery occlusion: glutamate elevation related to decrease of cerebral perfusion pressure. Stroke 33:1383-1391, 2002.

87. Dohman C, Bosche B, Graf R, Staub F, Kracht L, Sobesky J, et al. Prediction of malignant course in MCA infarction by PET and microdialysis. Stroke 34:2152-2158, 2003.

88. Thomalla G, Kucinski T, Schoder V, Fiehler J, Knab R, Zeummer $\mathrm{H}$, et al J. Prediction of malignant middle cerebral artery infarction by early perfusion-and diffusion-weighted magnetic resonance imaging. Stroke 34:1892-1900, 2003.
89. Tamura A, Graham DI, McCulloch J, Teasdale GM. Focal cerebral ischemia in the rat: 1 . Description of technique and early neuropathological consequences following middle cerebral artery occlusion. J Cereb Blood Flow Met 1:53-60, 1981.

90. Herz RC, Kasbergen CM, Hillen B, Versteeg DH, de Wildt DJ Rat middle cerebral artery occlusion by an intraluminal thread compromises collateral blood flow. Brain Res 791:223-228, 1998.

91. Guegan C, Sola B. Early and sequential recruitment of apoptotic effectors after focal permanent ischemia in mice. Brain Res 856 93-100, 2000.

92. Chen ST, Hsu CY, Hogan EL, Marico H, Balentine JD. A model of focal ischemic stroke in the rat: reproducible extensive cortical infarction. Stroke 17:738-743, 1986.

93. Rubino GJ, Young W. Ischemic cortical lesions after permanent occlusion of the individual middle cerebral artery branches in rats. Stroke 19:870-877, 1988.

94. Brint S, Jacewicz M, Kiessling M, Tanabe J, Pulsinelli W. Focal brain ischemia in the rat: methods for reproducible neocortical infarction using tandem occlusion of the distal middle cerebral and ipsilateral common carotid arteries. J Cereb Blood Flow Metab 8:474-483, 1988.

95. Yanamoto H, Nagata I, Niitsu Y, Xue J, Zhang Z, Kikuchi H. Evaluation of MCAO stroke models in normotensive rats: standardized neocortical infarction by the $3 \mathrm{VO}$ tecnique. Exp Neurol 182:261-274, 2003

96. Buchan AM, Xue D, Slivka A. A new model of temporary focal neocortical ischemia in the rat. Stroke 23:273-279, 1992.

97. Lin TN, Sun SW, Cheung WM, Li F, Chang C. Dynamic changes in cerebral blood flow and angiogenesis after transient focal cerebral ischemia in rats. Stroke 33:2985-2991, 2002.

98. Herz RC, Hillen B, Versteeg DH, De Wildt DJ. Collateral hemodynamics after middle cerebral artery occlusion in Wistar and Fischer-344 rats. Brain Res 793:289-296, 1998.

99. Gerriets T, Li F, Silva MD, Meng X, Brevard M, Sotak CH, Fisher M. The macrosphere model: evaluation of a new stroke model for permanent middle cerebral artery occlusion in rats. J Neurosci Methods 122:201-211, 2003.

100. Miyake M, Takeo S, Kaijihara H. Sustained decrease in regional blood flow after microsphere injection in rats. Stroke 24:415$420,1993$.

101. Mayzel-Oreg O, Omae T, Kazemi M, Li F, Fisher M, Cohen Y, et al. Microsphere-induced embolic stroke: an MRI study. Magn Reson Med 51:1232-1238, 2004.

102. Zhang Z, Zhang RL, Jiang Q, Raman SB, Cantwell L, Chopp M. A new rat model of thrombotic focal cerebral ischemia. J Cereb Blood Flow Metab 17:123-135, 1997.

103. Beech JS, Williams SC, Campbell CA, Bath PM, Parsons AA, Hunter AJ, et al. Further characterisation of a thromboembolic model of stroke in the rat. Brain Res 895:18-24, 2001.

104. Wang CX, Todd KG, Yang Y, Gordon T, Shuaib A. Patency of cerebral microvessels after focal embolic stroke in the rat. J Cereb Blood Flow Metab 21:413-421, 2001.

105. Niessen F, Hilger T, Hoehn M, Hossmann KA. Differences in clot preparation determine outcome of recombinant tissue plasminogen activator treatment in experimental thromboembolic stroke. Stroke 34:2019-2024, 2003.

106. Watson BD, Dietrich WD, Busto R, Wachtel MS, Ginsberg MD. Induction of reproducible brain infarction by photochemically initiated thrombosis. Ann Neurol 17:497-504, 1985.

107. Dietrich WD, Ginsberg MD, Busto R, Watson BD. Photochemically induced cortical infarction in the rat. 2. Acute and subacute alterations in local glucose utilization. J Cereb Blood Flow Metab 6:195-202, 1986.

108. Dietrich WD, Watson BD, Busto R, Ginsberg MD. Metabolic plasticity following cortical infarction: a 2-deoxyglucose study. In: Cerebrovascular disorders (Raichel ME, Powers WJ, eds), pp 285-295. New York: Raven Press, 1987.

109. Que M, Schiene K, Witte OW, Zilles K. Widespread up-regulation of N-methyl-D-aspartate receptors after focal photothrombotic lesion in rat brain. Neurosci Lett 273:77-80, 1999.

110. Braun JS, Jander S, Schroeter M, Witte OW, Stoll G. Spatiotemporal relationship of apoptotic cell death to lymphomonocytic 
infiltration in photochemically induced focal ischemia of the rat cerebral cortex. Acta Neuropathol (Berl) 92:255-263, 1996.

111. Kim GW, Sugawara T, Chan PH. Involvement of oxidative stress and caspase-3 in cortical infarction after photothrombotic ischemia in mice. J Cereb Blood Flow Metab 20:1690-1701, 2000.

112. Schroeter M, Jander S, Huitinga I, Witte OW, Stoll G. Phagocytic response in photochemically induced infarction of rat cerebral cortex. The role of resident microglia. Stroke 28:382-386, 1997.

113. Jander S, Schroeter M, Stoll G. Role of NMDA receptor signaling in the regulation of inflammatory gene expression after focal brain ischemia. J Neuroimmunol 109:181-187, 2000.

114. Hayashi T, Sakurai M, Itoyama Y, Abe K. Oxidative damage and breakage of DNA in rat brain after transient MCA occlusion. Brain Res 832:159-163, 1999.

115. Katsman D, Zheng J, Spinelli K, Carmichael ST. Tissue microenvironments within functional cortical subdivisions adjacent to focal stroke. J Cereb Blood Flow Metab 23:997-1009, 2003.

116. van Bruggen N, Cullen BM, King MD, Doran M, Williams SR, Gadian DG, et al. T2- and diffusion-weighted magnetic resonance imaging of a focal ischemic lesion in rat brain. Stroke 23:576582, 1992.

117. Lee VM, Burdett NG, Carpenter A, Hall LD, Pambakian PS, Patel S, Wood NI, James MF. Evolution of photochemically induced focal cerebral ischemia in the rat. Magnetic resonance imaging and histology. Stroke 27:2110-2118, 1996.

118. Provenzale JM, Jahan R, Naidich TP, Fox AJ. Assessment of the patient with hyperacute stroke: imaging and therapy. Radiology 229:347-359, 2003.

119. Albensi BC, Knoblach SM, Chew BG, O'Reilly MP, Faden AI, Pekar JJ. Diffusion and high resolution MRI of traumatic brain injury in rats: time course and correlation with histology. Exp Neurol 162:61-72, 2000.

120. Schneider G, Fries P, Wagner-Jochem D, Thome D, Laurer H, Kramann B, et al. Pathophysiological changes after traumatic brain injury: comparison of two experimental animal models by means of MRI. MAGMA 14:233-241, 2003.

121. Hu X, Wester P, Brannstrom T, Watson BD, Gu W. Progressive and reproducible focal cortical ischemia with or without late spontaneous reperfusion generated by a ring-shaped, laser-driven photothrombotic lesion in rats. Brain Res Brain Res Protoc 7:7685, 2001.

122. Witte OW, Stoll G. Delayed and remote effects of focal cortical infarctions: secondary damage and reactive plasticity. Adv Neurol 73:207-227, 1997.

123. Hagemann G, Redecker C, Neumann-Haefelin T, Freund HJ, Witte OW. Increased long-term potentiation in the surround of experimentally induced focal cortical infarction. Ann Neurol 44: 255-258, 1998.

124. Neumann-Haefelin T, Staiger JF, Redecker C, Zilles K, Fritschy $\mathrm{JM}$, Mohler H, et al. Immunohistochemical evidence for dysregulation of the GABAergic system ipsilateral to photochemically induced cortical infarcts in rats. Neuroscience 87:871-879, 1998.

125. Carmichael ST, Wei L, Rovainen CM, Woolsey TA. New patterns of intracortical projections after focal cortical stroke. Neurobiol Dis 8:910-922, 2001.

126. Arvidsson A, Collin T, Kirik D, Kokaia Z, Lindvall O. Neuronal replacement from endogenous precursors in the adult brain after stroke. Nat Med 8:963-970, 2002.

127. Parent JM, Vexler ZS, Gong C, Derugin N, Ferriero DM. Rat forebrain neurogenesis and striatal neuron replacement after focal stroke. Ann Neurol 52:802-813, 2002.

128. Nudo RJ, Wise BM, SiFuentes F, Milliken GW. Neural substrates for the effects of rehabilitative training on motor recovery after ischemic infarct. Science 272:1791-1794, 1996.

129. Longa EZ, Weinstein PR, Carlson S, Cummins R. Reversible middle cerebral artery occlusion without craniectomy in rats. Stroke 20:84-91, 1989.

130. Cox SB, Woolsey TA, Rovainen CM. Localized dynamic changes in cortical blood flow with whisker stimulation corresponds to matched vascular and neuronal architecture of rat barrels. J Cereb Blood Flow Metab 13:899-913, 1993.

131. Wei L, Rovainen CM, Woolsey TA. Ministrokes in rat barrel cortex. Stroke 26:1459-1462, 1995.
132. Li S, Zheng J, Carmichael ST. Increased oxidative protein and DNA damage but decreased stress response in the aged brain following experimental stroke. Neurobiol Dis 18:432-440, 2005.

133. Carmichael ST, Archibeque I, Luke L, Nolan T, Momiy J, Li S. Growth-associated gene expression after stroke: evidence for a regenerative zone in peri-infarct cortex. Exp Neurol, in press.

134. Masaki T, Yanagisawa M. Endothelins. Essays Biochem 27:7989, 1992.

135. Hughes PM, Anthony DC, Ruddin M, Botham MS, Rankine EL, Sablone M, et al. Focal lesions in the rat central nervous system induced by endothelin-1. J Neuropathol Exp Neurol 62:12761286, 2003.

136. Fuxe K, Bjelke B, Andbjer B, Grahn H, Rimondini R, Agnati LF. Endothelin-1 induced lesions of the frontoparietal cortex of the rat. A possible model of focal cortical ischemia. Neuroreport 8:2623-2629, 1997.

137. Adkins-Muir DL, Jones TA. Cortical electrical stimulation combined with rehabilitative training: enhanced functional recovery and dendritic plasticity following focal cortical ischemia in rats. Neurol Res 25:780-788, 2003.

138. Luke LM, Allred RP, Jones TA. Unilateral ischemic sensorimotor cortical damage induces contralesional synaptogenesis and enhances skilled reaching with the ipsilateral forelimb in adult male rats. Synapse, in press.

139. Gilmour G, Iversen SD, O’Neill MF, Bannerman DM. The effects of intracortical endothelin-1 injections on skilled forelimb use: implications for modelling recovery of function after stroke. Behav Brain Res 150:171-183, 2004.

140. Nakagomi S, Kiryu-Seo S, Kiyama H. Endothelin-converting enzymes and endothelin receptor B messenger RNAs are expressed in different neural cell species and these messenger RNAs are coordinately induced in neurons and astrocytes respectively following nerve injury. Neuroscience 101:441-449, 2000.

141. Naidoo V, Naidoo S, Mahabeer R, Raidoo DM. Cellular distribution of the endothelin system in the human brain. $J$ Chem Neuroanat 27:87-98, 2004.

142. Uesugi M, Kasuya Y, Hama H, Yamamoto M, Hayashi K, Masaki T, Goto K. Endogenous endothelin-1 initiates astrocytic growth after spinal cord injury. Brain Res 728:255-259, 1996.

143. Uesugi M, Kasuya Y, Hayashi K, Goto K. SB209670, a potent endothelin receptor antagonist, prevents or delays axonal degeneration after spinal cord injury. Brain Res 786:235-259, 1998.

144. Tagaya M, Liu KF, Copeland B, Seiffert D, Engler R, Garcia JH, et al. DNA scission after focal brain ischemia. Temporal differences in two species. Stroke 28:1245-1254, 1997.

145. Fukuda S, del Zoppo GJ. Models of focal cerebral ischemia in the nonhuman primate. ILAR J 44:96-104, 2004.

146. Belayev L, Khoutorova L, Xhang Y, Belayev A, Zhao W, Busto $\mathrm{R}$, et al. Caffeinol confers cortical but not subcortical neuroprotection after transient focal cerebral ischemia in rats. Brain Res 1008:278-283, 2004.

147. Inoue S, Drummond JC, Davis DP, Cole DJ, Patel PM. Combination of isoflurane and caspase inhibition reduces cerebral injury in rats subjected to focal cerebral ischemia. Anesthesiology 101: 75-81, 2004.

148. Matucz E, Moricz K, Gigler G, Simo A, Barkoczy J, Levay G, et al. Reduction of cerebral infarct size by non-competitive AMPA antagonists in rats subjected to permanent and transient focal ischemia. Brain Res 1019:210-216, 2004.

149. Cervera A, Justicia C, Reverter JC, Planas AM, Chamorro A. Steady plasma concentration of unfractionated heparin reduces infarct volume and prevents inflammatory damage after transient focal cerebral ischemia in the rat. $J$ Neurosci Res 77:565-572, 2004.

150. Virley D, Beech JS, Smart SC, Williams SC, Hodges H, Hunter AJ. A temporal MRI assessment of neuropathology after transient middle cerebral artery occlusion in the rat: correlations with behavior. J Cereb Blood Flow Metab 20:563-582, 2000.

151. Andrabi SA, Spina MG, Lorenz P, Ebmeyer U, Wolf G, Horn TF. Oxyresveratrol (trans-2,3',4,5' -tetrahydroxystilbene) is neuroprotective and inhibits the apoptotic cell death in transient cerebral ischemia. Brain Res 1017:98-107, 2004.

152. Petty MA, Neumann-Haefelin C, Kalisch J, Sarhan S, Wettstein 
JG, Juretschke HP. In vivo neuroprotective effects of ACEA 1021 confirmed by magnetic resonance imaging in ischemic stroke. Eur J Pharmacol 474:53-62, 2003.

153. Williams AJ, Hale SL, Moffett JR, Dave JR, Elliott PJ, Adams J, et al. Delayed treatment with MLN519 reduces infarction and associated neurologic deficit caused by focal ischemic brain injury in rats via antiinflammatory mechanisms involving nuclear factor- $\kappa \mathrm{B}$ activation, gliosis, and leukocyte infiltration. $J$ Cereb Blood Flow Metab 23:75-87, 2003.

154. Andersen M, Overgaard K, Meden P, Boysen G, Choi SC. Effects of citicoline combined with thrombolytic therapy in a rat embolic stroke model. Stroke 30:1464-1471, 1999.

155. Takamatsu H, Tatsumi M, Nitta S, Ichise R, Muramatsu K, Iida $\mathrm{M}$, et al. Time courses of progress to the chronic stage of middle cerebral artery occlusion models in rats. Exp Brain Res 146:95102, 2002.

156. Boutin H, LeFeuvre RA, Horai R, Asano M, Iwakura Y, Rothwell NJ. Role of IL- $1 \alpha$ and IL- $1 \beta$ in ischemic brain damage. $J$ Neurocsi 21:5528-5534, 2001.

157. Borsello T, Clarke PG, Hirt L, Vercelli A, Repici M, Schorderet DF, Bogousslavsky J, Bonny C. A peptide inhibitor of c-Jun $\mathrm{N}$-terminal kinase protects against excitotoxicity and cerebral ischemia. Nat Med 9:1180-1186, 2003.

158. Yu F, Sugawara T, Chan PH. Treatment with dihydroethidium reduces infarct size after transient focal cerebral ischemia in mice. Brain Res 978:223-227, 2003.

159. Gibson CL, Murphy SP. Progesterone enhances functional recovery after middle cerebral artery occlusion in male mice. J Cereb Blood Flow Metab 24:805-813, 2004.

160. Luo Y, Qin Z, Hong Z, Zhang X, Ding D, Fu JH, et al. Astragaloside IV protects against ischemic brain injury in a murine model of transient focal ischemia. Neurosci Lett 363:218-223, 2004.

161. Wexler EJ, Peters EE, Gonzales A, Gonzales ML, Slee AM, Kerr JS. An objective procedure for ischemic area evaluation of the stroke intraluminal thread model in the mouse and rat. $J$ Neurosci Methods 113:51-58, 2002.

162. Shichinohe H, Kuroda S, Abumiya T, Ikeda J, Kobayashi T, Yoshimoto T, et al. FK506 reduces infarct volume due to permanent focal cerebral ischemia by maintaining BAD turnover and inhibiting cytochrome c release. Brain Res 1001:51-519, 2004.

163. Yanamoto H, Nagata I, Hashimoto N, Kikuchi H. Three-vessel occlusion using a micro-clip for the proximal left middle cerebral artery produces a reliable neocortical infarct in rats. Brain Res Brain Res Protoc 3:209-220, 1998.

164. McDaniel B, Sheng H, Warner DS, Hedlund LW, Benveniste H. Tracking brain volume changes in C57BL/6J and ApoE-deficient mice in a model of neurodegeneration: a 5-week longitudinal micro-MRI study. Neuroimage 14:1244-1255, 2001.

165. Saver JL, Johnston KC, Homer D, Wityk R, Koroshetz W, Truskowski LL, Haley EC. Infarct volume as a surrogate or auxiliary outcome measure in ischemic stroke clinical trials. The RANTTAS Investigators. Stroke 30:293-298, 1999.

166. Mori K, Aoki A, Yamamoto T, Horinaka N, Maeda M. Aggressive decompressive surgery in patients with massive hemispheric embolic cerebral infarction associated with severe brain swelling. Acta Neurochir (Wien) 143:483-491, 2001.

167. Oppenheim C, Samson Y, Manai R, Lalam T, Vandamme X, Crozier S, et al. Prediction of malignant middle cerebral artery infarction by diffusion-weighted imaging. Stroke 31:2175-2181, 2000.

168. Foerch C, Otto B, Singer OC, Neumann-Haefelin T, Yan B, Berkefeld J, et al. Serum S100B predicts a malignant course of infarction in patients with acute middle cerebral artery occlusion. Stroke 35:2160-2164, 2004.

169. Kim JH, Yenari MA, Giffard RG, Cho SW, Park KA, Lee JE. Agmatine reduces infarct area in a mouse model of transient focal cerebral ischemia and protects cultured neurons from ischemialike injury. Exp Neurol 189:122-130, 2004. 